\title{
Regulation of 2-deoxyglucose phosphate accumulation in Lactococcus lactis vesicles by metabolite-activated, ATP-dependent phosphorylation of serine-46 in HPr of the phosphotransferase system
}

\author{
Jing Jing Ye, Jonathan Reizer and Milton H. Saier, Jr \\ Author for correspondence: Milton H. Saier, Jr. Tel: +1619534 4084. Fax: +1 6195347108. \\ e-mail: msaier@ucsd.edu
}

Department of Biology, University of California at San Diego, La Jolla, CA 92093-0116, USA

\begin{abstract}
Lactococcus lactis takes up glucose and the nonmetabolizable glucose analogue 2-deoxyglucose (2DG) via the phosphotransferase system and extrudes the accumulated sugar phosphates in a process apparently dependent on a cytoplasmic sugar-phosphate phosphatase. Uptake of 2DG into L. lactis vesicles was shown to be dependent on an energy source, effectively provided by intravesicular phosphoenolpyruvate (PEP). 2DG phosphate (2DG-P) accumulation in these vesicles was not inhibited, and preaccumulated 2DG-P was not released from them, upon electroporation of fructose 1,6-diphosphate (FDP), gluconate 6-phosphate or 2-phosphoglycerate into the vesicles. Intravesicular but not extravesicular wild-type HPr of Bacillus subtilis alone stimulated uptake, but in the presence of any one of these metabolites, it prevented accumulation of 2DG-P. Intravesicular H15A mutant HPr inhibited uptake and allowed further inhibition of 2DG-P accumulation in the presence of the intravesicular metabolites. Intravesicular S46A mutant HPr stimulated uptake but could not promote inhibition in the presence of the phosphorylated metabolites. The S46D mutant HPr protein promoted regulation, even in the absence of a metabolite. The $\boldsymbol{V}_{\max }$ but not the $K_{m}$ value for 2DG uptake was affected. Accumulation of the natural, metabolizable substrates of the lactose, glucose, mannose and ribose permeases was inhibited by wild-type HPr in the presence of FDP or by S46D mutant HPr. The results establish that HPr serine phosphorylation by the ATP-dependent, metabolite-activated HPr kinase selectively determines the levels of sugar accumulation via the glucose and lactose permeases in L. lactis. They suggest that two primary functions of HPr(Ser) phosphorylation are : (1) to feedback-inhibit the activities of carbohydrate permeases and not merely to create a hierarchy of preferred carbon sources, and (2) to regulate the cytoplasmic concentrations of carbohydrate inducers by exclusion and expulsion mechanisms.
\end{abstract}

Keywords: sugar transport, Lactococcus lactis, phosphotransferase system, HPr, protein kinase

\section{INTRODUCTION}

Many low-GC Gram-positive bacteria possess the phosphoenolpyruvate: sugar phosphotransferase system (PTS)

Abbreviations: 2DG, 2-deoxyglucose, FDP, fructose 1,6-diphosphate; - $P$, phosphate, PEP, phosphoenolpyruvate; PTS, phosphotransferase system; TMG, thiomethyl $\beta$-galactoside (methyl $\beta$-D-thiogalactopyranoside). that catalyses the concomitant uptake and phosphorylation of its sugar substrates. The PTS-catalysed process requires the sequential phosphorylation of four proteins or protein domains, Enzyme I, HPr, IIA ${ }^{\text {sugar }}$ and IIB ${ }^{\text {sugar }}$, before sugar phosphorylation and concomitant transport can occur (Saier \& Reizer, 1992; Postma et al., 1993). The PTS proteins function in numerous biochemical and genetic regulatory capacities (Saier, 1985, 1989a, b; Saier 
et al., 1992). In early studies, it was shown that addition of a rapidly metabolizable sugar such as glucose to streptococci, lactococci or lactobacilli resulted in inhibition of the uptake of other sugars (inducer exclusion) as well as rapid efflux of preaccumulated sugars or sugar metabolites (inducer expulsion). For example, lactose and its nonmetabolizable analogue thiomethyl $\beta$-galactoside (TMG) were taken up via the PTS in streptococci and lactococci but via $\mathrm{H}^{+}$symport in lactobacilli, and addition of glucose inhibited uptake as well as elicited expulsion of the preaccumulated galactoside (Reizer \& Panos, 1980; Thompson \& Saier, 1981; Reizer et al., 1983; Romano et al., 1987).

These in vivo studies led to the search for and discovery of an ATP-dependent, metabolite-activated HPr kinase and an $\mathrm{HPr}($ serine) $[\mathrm{HPr}(\mathrm{Ser})]$ phosphate phosphatase that reversibly phosphorylate HPr (Deutscher \& Saier, 1983). The kinase was shown to phosphorylate serine-46 in HPr and to be present in a wide variety of low-GC Gram-positive bacteria (see Reizer et al., 1988; Thompson, 1988, for reviews). Functions of HPr and its reversible ATP-dependent phosphorylation include (1) the regulation of net lactose PTS activity as demonstrated recently employing vesicles derived from Lactococcus lactis (Ye et al., 1994a), (2) regulation of a cytoplasmic sugarphosphate phosphatase in $L$. lactis that can prevent accumulation of intracellular sugar phosphates under conditions of metabolite excess, (3) regulation of lactose $: \mathrm{H}^{+}$and glucose: $\mathrm{H}^{+}$symport activities in Lactobacillus brevis (Ye et al., 1994b, c), and (4) regulation of catabolite repression in Bacillus subtilis (Deutscher $e t$ al., 1994).

Lactococcus lactis possesses both a lactose and a glucose PTS (Thompson \& Saier, 1981). In the work described here, we used $L$. lactis vesicles to test the postulate that $\mathrm{HPr}$ plays a direct role in the regulation of net glucose as well as net lactose permease activity of this organism. We show that accumulation of non-metabolizable sugar phosphates via both of these two transport systems is subject to inhibition by $\mathrm{HPr}(\operatorname{Ser}-\mathrm{P})$ by a qualitatively similar process. Moreover, metabolizable sugar uptake is also shown to be inhibited under conditions of $\mathrm{HPr}(\mathrm{Ser})$ phosphorylation. The results lead to the postulate that a primary function of $\mathrm{HPr}(\mathrm{Ser})$ phosphorylation in lactococci is indirect feedback inhibition of sugar phosphate accumulation by intracellular metabolites, a process that presumably prevents the uptake of sugar in excess of the needs of the cell and regulates the levels of inducers of carbohydrate catabolic operons.

\section{METHODS}

Organisms, growth and vesicle preparations. Growth conditions and the bacterial strain used, Lactococcus lactis $\mathrm{ML}_{3}$, were described previously (Thompson \& Saier, 1981; Ye et al., 1994a). Cells were grown for $18 \mathrm{~h}$ at $37^{\circ} \mathrm{C}$ in the presence of $25 \mathrm{mM}$ galactose, harvested, washed, and used directly for transport experiments or for preparation of membrane vesicles following the method described by Kaback (1972) for Escberichia coli with the modifications described previously (Ye et al., 1994a, b).

Uptake measurements. Cells or vesicles were suspended in $50 \mathrm{mM}$ Tris/maleate buffer $(\mathrm{pH} 7 \cdot 0)$ at a cell density of $1.5-2.0 \mathrm{mg}$ dry weight $\mathrm{ml}^{-1}$ or a vesicle density of $2 \mathrm{mg}$ protein $\mathrm{ml}^{-1}$. Various additions as specified in Results or as described below were made to a $100 \mu \mathrm{l}$ cell or vesicle suspension incubated at $30^{\circ} \mathrm{C} . \beta\left[\right.$ methy $\left.l-{ }^{14} \mathrm{C}\right]$ thiogalactopyranoside $\left(\left[{ }^{14} \mathrm{C}\right] \mathrm{TMG}\right)$ (New England Nuclear) was added to a final concentration of $60 \mu \mathrm{M}$ $\left(58 \mathrm{mCi} \mathrm{mmol}^{-1} ; 1 \mathrm{mCi}=37 \mathrm{MBq}\right)$ at zero time except where otherwise noted. 2-Deoxy $\left[{ }^{14} \mathrm{C}\right]$ glucose $\left(\left[{ }^{14} \mathrm{C}\right] 2 \mathrm{DG}\right)$ was added to a final concentration of $2 \mathrm{mM}\left(20 \mathrm{mCi} \mathrm{mmol}^{-1}\right)$ at zero time, except where otherwise noted. Other radioactive sugars examined were used at concentrations and specific activities as specified in the footnote to Table 4. The energy source [phosphoenolpyruvate (PEP), $50 \mathrm{mM}$ ] was usually added to the vesicle suspension at $t=-1 \mathrm{~min}$ while glucose or other potential external inhibitors were added at $t=-5 \mathrm{~min}$. Samples of 10-20 $\mu \mathrm{l}$ were removed at appropriate intervals, filtered on $25 \mathrm{~mm}$ membrane filters $(0.45 \mu \mathrm{m}$ pore size; Millipore), and washed with cold $50 \mathrm{mM}$ Tris/maleate buffer $(\mathrm{pH} 7 \cdot 0)$. Washed filters with cells or vesicles were then transferred to vials containing $5 \mathrm{ml}$ scintillation fluid for determination of radioactivity. All data reported are the means of three or four experiments.

Preparation of $\left[{ }^{14} \mathrm{C}\right] 2 \mathrm{DG}$-loaded vesicles for efflux studies. The preloading medium $(100 \mu \mathrm{l})$ contained $50 \mathrm{mM}$ Tris/maleate buffer $(\mathrm{pH} 7 \cdot 0), 2 \mathrm{mM}\left[{ }^{14} \mathrm{C}\right] 2 \mathrm{DG}\left(20 \mathrm{mCi} \mathrm{mmol}^{-1}\right)$ and $200 \mu \mathrm{g}$ L. lactis vesicle protein. Following an incubation period of $10 \mathrm{~min}$ at $30^{\circ} \mathrm{C}$, after which time the maximal accumulation level of $\left[{ }^{14} \mathrm{C}\right] 2 \mathrm{DG}$ in $L$. lactis vesicles had been achieved, the suspension was chilled rapidly to $0^{\circ} \mathrm{C}$. When appropriate, vesicles were then subjected to electroporation with designated compounds present as specified below. Because less than $20 \%$ of the preloaded radioactive sugar or sugar phosphate was lost during electroporation, we presume that the vesicles reseal essentially quantitatively very quickly following completion of the procedure (see below). The vesicles were collected by centrifugation $(12000 \mathrm{~g}, 1 \mathrm{~min})$, the supernatant fluid was removed by aspiration, and excess liquid was removed with cotton buds. The $\left[{ }^{14} \mathrm{C}\right] 2 \mathrm{DG}$-loaded vesicle pellet was resuspended in $100 \mu \mathrm{l}$ ice-cold $50 \mathrm{mM}$ Tris/maleate buffer ( $\mathrm{pH} 7.0$ ) by rapid vortex mixing. More than $90 \%$ of the accumulated radioactive sugar was shown to be present as the phosphate ester as described previously (Ye et al., 1994a). The $100 \mu \mathrm{l}$ suspension (equivalent to $0.2 \mathrm{mg}$ vesicle protein) was used for 2DG efflux studies. 10-20 $\mu$ l aliquots were periodically removed for determination of intravesicular $\left[{ }^{14} \mathrm{C}\right] 2 \mathrm{DG}$ as indicated above.

Electroporation of $\mathrm{HPr}$ and metabolites into vesicles. $B$. subtilis $\mathrm{HPr}$ (usually at $100 \mu \mathrm{M}$ ) or one of the mutant $\mathrm{HPr}$ proteins, H15A, S46A or S46D (also at $100 \mu \mathrm{M}$ ) (Reizer et al., 1989), was added to a Gene Pulser cuvette $(0.2 \mathrm{~cm}$; Bio-Rad) containing $50-100 \mu \mathrm{l} \mathrm{L}$. lactis vesicles. The mixture was then electroporated twice at $0{ }^{\circ} \mathrm{C}$ and $700 \mathrm{~V}$ for $1.5 \mathrm{~ms}$ at a resistance of $200 \Omega$ and a capacitance of $25 \mu \mathrm{F}$. It was left on ice for at least $10 \mathrm{~min}$ but not more than $30 \mathrm{~min}$ before the electroporated vesicles were used for $2 \mathrm{DG}$ uptake or efflux studies as described above.

Materials and protein assays. Chemicals were purchased from Sigma and were of the highest purity available. Wild-type and mutant forms of $\mathrm{HPr}$ were purified to homogeneity after overexpression as detailed elsewhere (Reizer et al., 1989). Protein concentrations and the protein contents of vesicles prepared from $L$. lactis cells were determined by the Lowry method. 

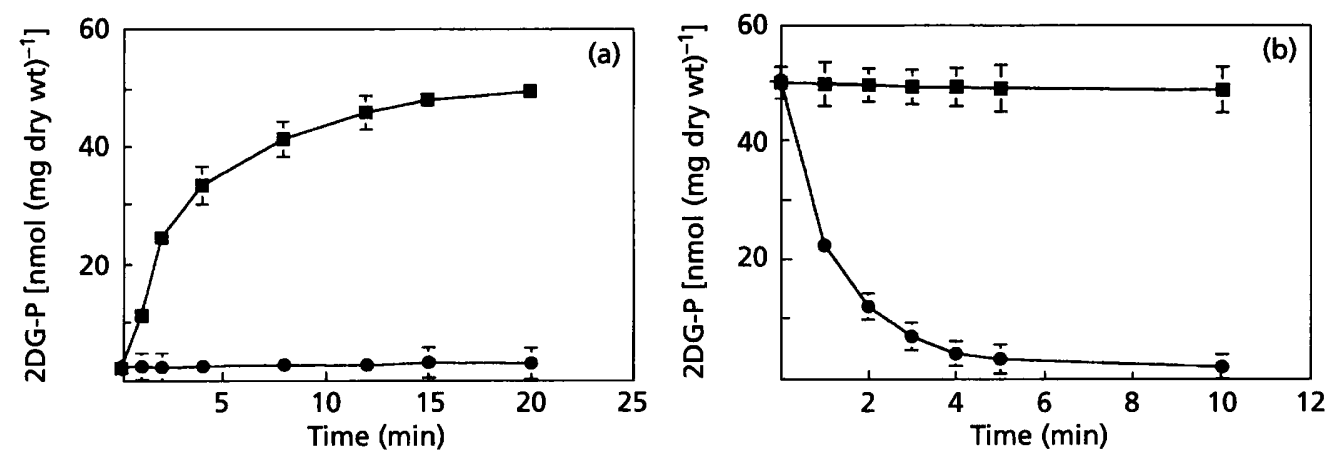

Fig. 1. Time courses for the uptake (a) and efflux (b) of $\left[{ }^{14} \mathrm{C}\right] 2 \mathrm{DG}$ using intact galactose-grown $L$. lactis cells. $\left[{ }^{14} \mathrm{C}\right] 2 \mathrm{DG}$ ( $2 \mathrm{mM}, 20 \mathrm{mCi} \mathrm{mmol}^{-1}$ ) accumulation was measured as described in Methods. For the uptake experiments (a), glucose was either lacking $(\square)$ or was added to a final concentration of $20 \mathrm{mM}(0) 5 \mathrm{~min}$ before the addition of the [ $\left.{ }^{14} \mathrm{C}\right] \mathrm{sugar}$. For the efflux experiments (b), glucose was either lacking $(\square)$ or was added at $t=0$ to a final concentration of $20 \mathrm{mM}(0)$. Cells were preloaded by preincubating them with $\left[{ }^{14} \mathrm{C}\right] 2 \mathrm{DG}$ for $10 \mathrm{~min}$, then chilling and centrifuging essentially as described for vesicles in Methods. The error bars in Figs $1-3$ represent SD $(n=3)$.

Table 1. Regulation of $2 D G$ uptake into $L$. lactis vesicles

PEP $(50 \mathrm{mM})$ was added to the vesicle preparation at $t=-1$ min unless otherwise indicated, $20 \mathrm{mM}$ FDP or gluconate 6-P and/or $100 \mu \mathrm{M}$ HPr or one of its derivatives was electroporated into the vesicles (as indicated by an e), or merely added to the extravesicular fluid at $t=-30 \mathrm{~s} .2 \mathrm{mM}$ $\left[{ }^{14} \mathrm{C}\right] 2 \mathrm{DG}$ (specific activity $20 \mathrm{mCi} \mathrm{mmol}^{-1}$ ) was added to the vesicle suspension at $t=0$, and samples were removed at $t=10 \mathrm{~min}$ for 2DG uptake measurement (see Methods). Values recorded are the amounts of radioactive sugar accumulated during this time interval. Values of three experiments were averaged and are reported \pm sD.

\begin{tabular}{|lc|}
\hline Preparation & $\begin{array}{c}\text { 2DG uptake } \\
\text { [nmol (mg protein) }{ }^{-1} \text { ] }\end{array}$ \\
\hline L. lactis vesicles alone (no PEP) & $17 \cdot 9 \pm 1 \cdot 2$ \\
L. lactis vesicles alone (50 mM PEP) & $26 \cdot 8 \pm 2 \cdot 3$ \\
+ $20 \mathrm{mM}$ FDP & $25 \cdot 6 \pm 2 \cdot 1$ \\
e/20 mM FDP & $23 \cdot 2 \pm 2 \cdot 7$ \\
+ $20 \mathrm{mM}$ gluconate 6-P & $24 \cdot 2 \pm 1 \cdot 7$ \\
e/20 mM gluconate 6-P & $25 \cdot 8 \pm 2 \cdot 8$ \\
e/100 $\mu \mathrm{M}$ HPr & $35 \cdot 0 \pm 3 \cdot 4$ \\
e/100 $\mu \mathrm{M}$ HPr, 20 mM FDP & $14 \cdot 4 \pm 1 \cdot 5$ \\
e/100 $\mu \mathrm{M}$ HPr, 20 mM gluconate 6-P & $15 \cdot 6 \pm 2 \cdot 0$ \\
e/100 $\mu \mathrm{M}$ H15A HPr & $18 \cdot 7 \pm 2 \cdot 2$ \\
e/100 $\mu \mathrm{M}$ H15A, 20 mM FDP & $12 \cdot 6 \pm 1 \cdot 0$ \\
e/100 $\mu \mathrm{M}$ H15A HPr, 20 mM gluconate 6-P & $14 \cdot 6 \pm 1 \cdot 8$ \\
e/100 $\mu \mathrm{M}$ S46D & $16 \cdot 6 \pm 1 \cdot 3$ \\
e/100 $\mu \mathrm{M}$ S46A & $34 \cdot 6 \pm 2 \cdot 8$ \\
e/100 $\mu \mathrm{M}$ S46A, 20 mM FDP & $33 \cdot 5 \pm 1 \cdot 6$ \\
\hline
\end{tabular}

\section{RESULTS}

\section{Inducer exclusion and expulsion in intact $L$. lactis cells}

The effect of glucose on the uptake and efflux of $\left[{ }^{14} \mathrm{C}\right] 2 \mathrm{DG}$ using intact cells of L. lactis is shown in Fig. 1. 2DG was rapidly accumulated against a concentration gradient, but when glucose was present, accumulation was blocked. Further, preaccumulated 2DG 6-P, which was stable in the cytoplasm of the washed cells, rapidly effluxed as the free sugar upon addition of glucose. The results are consistent with the conclusion that glucose metabolites regulate the glucose permease by a mechanism similar to that described previously for the lactose permease (Thompson \& Saier, 1981; Ye et al., 1994a).

\section{Regulation of 2DG accumulation in L. lactis membrane vesicles}

Vesicles prepared from $L$. lactis cells as described in Methods accumulated 2DG in the presence of PEP to an extent approaching that observed with intact cells (Table 

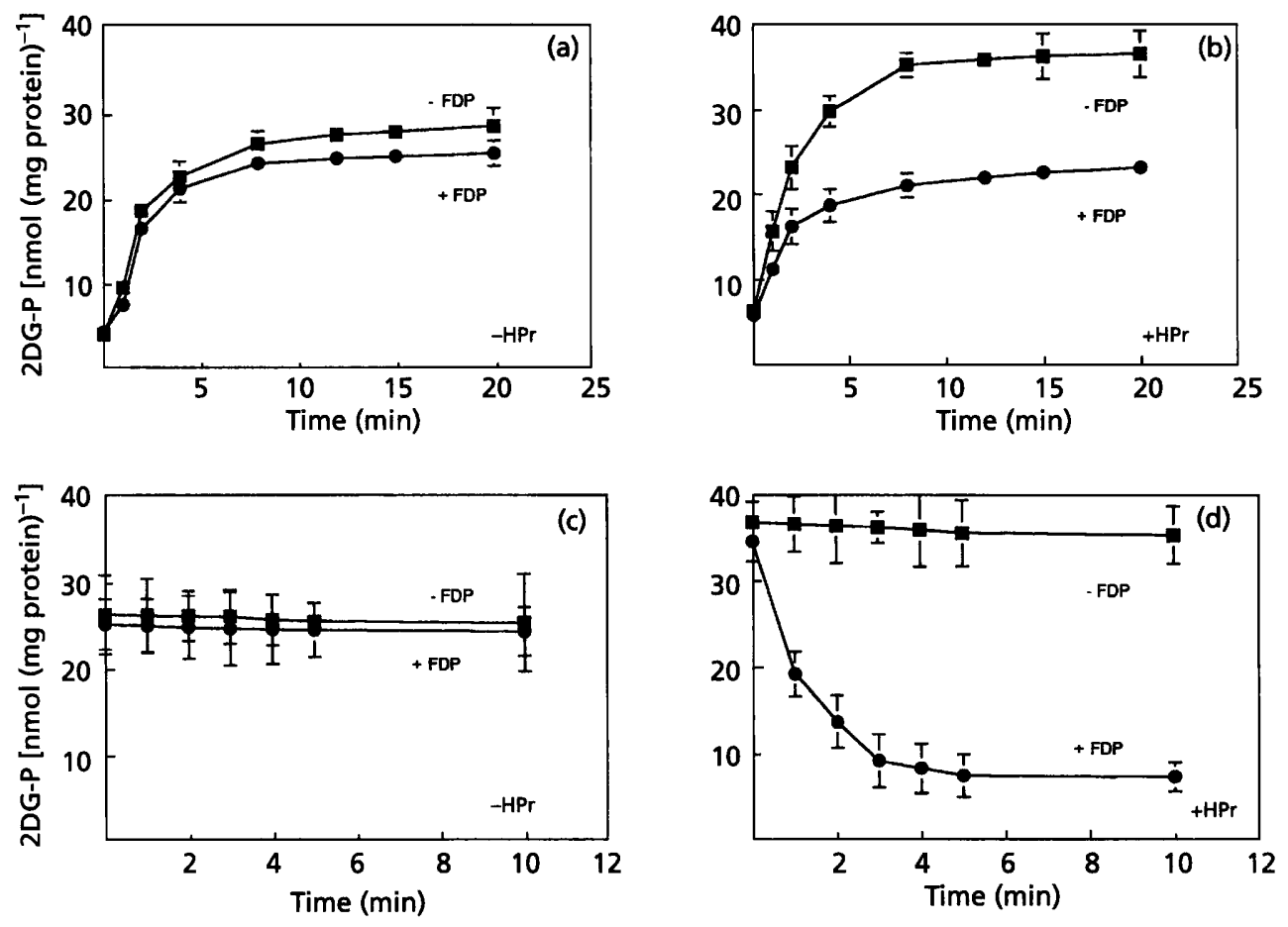

Fig. 2. Time courses for the uptake $(a, b)$ or efflux $(c, d)$ of $\left[{ }^{14} C\right] 2 D G$ using membrane vesicles of galactose-grown $L$. lactis cells with $50 \mathrm{mM}$ PEP as an energy source. FDP was either present at a concentration of $20 \mathrm{mM}(O)$ or absent ( $(\square)$ during electroporation of the vesicles as described in Methods. In (a) and (c), osmotically shocked vesicles were subjected to electroporation without $\mathrm{HPr}$. In (b) and (d), $\mathrm{HPr}(100 \mu \mathrm{M})$ was included during electroporation. The experimental protocol is described in Methods.
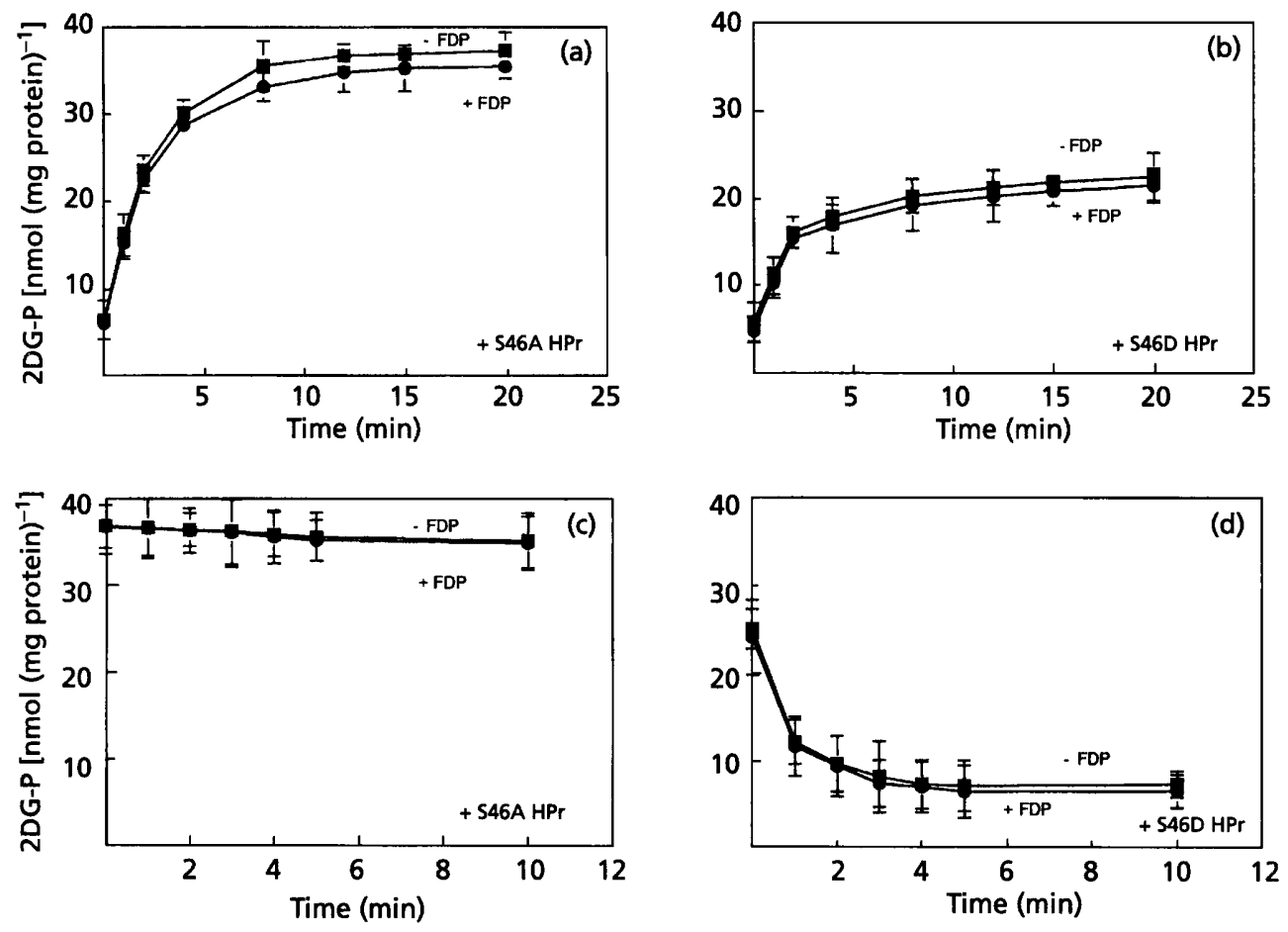

Fig. 3. Effects of intravesicular S46A ( $a, c)$ and S46D (b, d) mutant HPr proteins (each at $100 \mu \mathrm{M}$ during electroporation) on 2DG uptake into $(a, b)$ or efflux from $(c, d) L$. lactis vesicles with $(O)$ and without $(\square) 20 \mathrm{mM}$ FDP. The experimental protocol was as described in Methods. 
Table 2. Effects of metabolites on 2DG uptake into $L$. lactis vesicles

PEP $(20 \mathrm{mM})$ was added at $t=-1 \mathrm{~min}$, and $100 \mu \mathrm{M}$ HPr was electroporated into the vesicles together with the sugar or sugar metabolite indicated. $\left[{ }^{14} \mathrm{C}\right] 2 \mathrm{DG}$ (final concentration $2 \mathrm{mM}$, specific activity $20 \mathrm{mCi} \mathrm{mmol}^{-1}$ ) was added to the system at $t=0$, and samples were taken at $t=10 \mathrm{~min}$ for sugar uptake measurement (see Methods). Values recorded represent nmol $\left[{ }^{14} \mathrm{C}\right]$ sugar accumulated in a $10 \mathrm{~min}$ time interval per $\mathrm{mg}$ protein. Values of three experiments were averaged and are reported $\pm S D$.

\begin{tabular}{|lc|}
\hline Metabolite & $\begin{array}{c}\text { 2DG uptake } \\
\text { [nmol (mg protein) } \text { ( }^{-1} \text { ] }\end{array}$ \\
\hline Control (vesicles) & $35 \cdot 0 \pm 3 \cdot 4$ \\
Glucose & $3 \cdot 1 \pm 1 \cdot 1$ \\
Glucose 6-P & $34 \cdot 2 \pm 5 \cdot 2$ \\
Fructose 6-P & $33 \cdot 8 \pm 3 \cdot 7$ \\
FDP & $14 \cdot 4 \pm 2 \cdot 0$ \\
Mannose 6-P & $32 \cdot 4 \pm 4 \cdot 2$ \\
Ribose 5-P & $34 \cdot 2 \pm 2 \cdot 7$ \\
Ribulose 5-P & $34 \cdot 8 \pm 3 \cdot 2$ \\
Gluconate 6-P & $15 \cdot 6 \pm 3 \cdot 6$ \\
Glycerate 2-P & $17 \cdot 2 \pm 4 \cdot 1$ \\
Fructose 1-P & $35 \cdot 1 \pm 2 \cdot 3$ \\
Glucose 1-P & $34 \cdot 8 \pm 4 \cdot 2$ \\
Glucose 1,6-diP & $34 \cdot 7 \pm 3 \cdot 2$ \\
PEP & $34 \cdot 9 \pm 3 \cdot 7$ \\
Pyruvate & $35 \cdot 2 \pm 1 \cdot 2$ \\
Glycerate 3-P & $34 \cdot 3 \pm 1 \cdot 9$ \\
Lactate & $34 \cdot 4 \pm 3 \cdot 2$ \\
Gluconate & $34 \cdot 2 \pm 4 \cdot 5$ \\
\hline
\end{tabular}

1, Fig. 2a). Using an ion-exchange resin (Kundig \& Roseman, 1971), more than $90 \%$ of the accumulated radioactivity was shown to be 2DG-P. Less than $10 \%$ was free 2DG (data not shown). As shown in Table 1, 2DG accumulation was enhanced by PEP. Electroporation of wild-type or S46A mutant HPr into the vesicles stimulated uptake further, although H15A HPr or S46D HPr alone inhibited as expected. The H15A protein is catalytically inactive but can compete with the residual native $\mathrm{HPr}$ in the vesicles, and further, it can be phosphorylated by the kinase. The S46D mutant protein is locked in the inhibitory conformation (Wittekind et al., 1990).

Electroporation of fructose 1,6-diphosphate (FDP) or gluconate 6-phosphate (gluconate 6-P) into the vesicles did not result in inhibition of $2 D G$ uptake, but when one of these two metabolites as well as wild-type HPr or the H15A mutant protein was electroporated into the vesicles, metabolite-promoted inhibition was observed (Table 1). FDP appeared to be more effective than gluconate 6-P (which was apparently more effective than 2-phosphoglycerate, see Table 2 and below). Electroporation of S46A HPr into the vesicles did not promote inhibition of 2DG uptake by intravesicular FDP. These results are qualitatively similar to those we reported previously for the accumulation of TMG by $L$. lactis vesicles (Ye et al., 1994a).

Figs 2(a)-2(d) present time courses for 2DG uptake into and efflux from vesicles which had been electroporated in the presence or absence of wild-type B. subtilis HPr with or without FDP. In the absence of electroporated HPr, FDP neither inhibited uptake nor stimulated efflux appreciably (Fig. 2a, c). However, with wild-type $\mathrm{HPr}$ present in the vesicles, intravesicular FDP inhibited 2DG uptake while stimulating efflux of preaccumulated 2DG (Fig. 2b, d).

\section{Dependency of regulation on serine-46 in HPr}

Fig. 3 portrays time courses for $2 \mathrm{DG}$ uptake experiments in which intravesicular wild-type $B$. subtilis $\mathrm{HPr}$ was replaced with a mutant form of $\mathrm{HPr}$ with serine-46 replaced with a neutral alanyl residue (S46A; Fig. 3a, c) or

\section{Table 3. Effects of $\mathrm{Mg}^{2+}$ and $\mathrm{Mg}^{2+}-\mathrm{ATP}$ on regulation of $2 \mathrm{DG}$ and TMG uptake into $\mathrm{L}$. lactis vesicles}

PEP $(50 \mathrm{mM})$ was added at $t=-1 \mathrm{~min}$, and $100 \mu \mathrm{M} \mathrm{HPr}$ in the presence or absence of $20 \mathrm{mM} \mathrm{Mg}^{2+}$ or $\mathrm{Mg}^{2+}$-ATP was electroporated (as indicated by letter e) into the vesicles together with $20 \mathrm{mM}$ of the sugar metabolite indicated. $\left[{ }^{14} \mathrm{C}\right] \mathrm{TMG}$ (final concentration $60 \mu \mathrm{M}$, specific activity $58 \mathrm{mCi} \mathrm{mmol}^{-1}$ ) or $\left[{ }^{14} \mathrm{C}\right] 2 \mathrm{DG}$ (final concentration $2 \mathrm{mM}$, specific activity $20 \mathrm{mCi} \mathrm{mmol}^{-1}$ ) was added to the system at $t=0$, and samples were removed at $t=10 \mathrm{~min}$ for sugar uptake measurement (see Methods). Values recorded reflect the amount of the radioactive substrate accumulated during this time interval. Values of three experiments were averaged and are reported \pm SD.

\begin{tabular}{|c|c|c|c|c|c|c|}
\hline \multirow[t]{2}{*}{ Preparation } & \multicolumn{3}{|c|}{$\begin{array}{c}\text { 2DG uptake } \\
\left.[\text { nmol (mg protein) })^{-1}\right]\end{array}$} & \multicolumn{3}{|c|}{$\begin{array}{c}\text { TMG uptake } \\
\left.[\text { nmol (mg protein })^{-1}\right]\end{array}$} \\
\hline & $-\mathbf{M g}^{2+}-\mathbf{A T P}$ & $+\mathrm{e} / \mathrm{Mg}^{2+}$ & $+\mathrm{e} / \mathbf{M g}^{2+}-\mathbf{A} T \mathbf{P}$ & $-\mathbf{M g}^{2+}-\mathbf{A T P}$ & $+\mathrm{e} / \mathrm{Mg}^{2+}$ & $+\mathrm{e} / \mathbf{M g}^{2+}-\mathbf{A T P}$ \\
\hline Vesicles & $26 \cdot 8 \pm 2 \cdot 3$ & $23 \cdot 5 \pm 2 \cdot 1$ & $23 \cdot 1 \pm 1 \cdot 7$ & $10 \cdot 4 \pm 2 \cdot 2$ & $9 \cdot 7 \pm 1 \cdot 7$ & $9 \cdot 4 \pm 1 \cdot 9$ \\
\hline Vesicles $(\mathrm{e} / \mathrm{HPr}, 100 \mu \mathrm{M})$ & $35 \cdot 0 \pm 3 \cdot 4$ & $22 \cdot 0 \pm 2 \cdot 5$ & $22 \cdot 1 \pm 3 \cdot 6$ & $13 \cdot 7 \pm 1 \cdot 6$ & $9 \cdot 2 \pm 1 \cdot 0$ & $9 \cdot 1 \pm 1 \cdot 1$ \\
\hline$+\mathrm{e} / \mathrm{FDP}$ & $14 \cdot 4 \pm 2 \cdot 0$ & $13.9 \pm 2.5$ & $13 \cdot 8 \pm 2 \cdot 1$ & $1 \cdot 3 \pm 0 \cdot 2$ & $1.5 \pm 0.5$ & $1 \cdot 1 \pm 0 \cdot 6$ \\
\hline$+\mathrm{e} /$ Glucose 6-P & $34 \cdot 2 \pm 5 \cdot 2$ & $20 \cdot 8 \pm 2 \cdot 4$ & $15 \cdot 2 \pm 3 \cdot 3$ & $12 \cdot 7 \pm 1 \cdot 8$ & $8 \cdot 8 \pm 1 \cdot 1$ & $4 \cdot 3 \pm 1 \cdot 9$ \\
\hline e/Frucose 6-P & $33.8 \pm 3 \cdot 7$ & $20 \cdot 2 \pm 2 \cdot 9$ & $15 \cdot 4 \pm 2 \cdot 8$ & $9 \cdot 9 \pm 3 \cdot 7$ & $8 \cdot 2 \pm 1 \cdot 3$ & $4 \cdot 1 \pm 1 \cdot 1$ \\
\hline
\end{tabular}


Table 4. Regulation of sugar uptake into $L$. lactis vesicles

Conditions were essentially the same as for the experiments described in Table 1 except that uptake was for $1 \mathrm{~min}$ and the sugars were present as follows: $60 \mu \mathrm{M}\left[{ }^{14} \mathrm{C}\right] \mathrm{TMG}$ (specific activity $58 \mathrm{mCi} \mathrm{mmol}^{-1}$ ), $1 \mathrm{mM}\left[{ }^{14} \mathrm{C}\right]$ glucose (specific activity $5 \mathrm{mCi} \mathrm{mmol}^{-1}$ ), $0.3 \mathrm{mM}\left[{ }^{14} \mathrm{C}\right]$ lactose (specific activity $3 \mathrm{mCi} \mathrm{mmol}^{-1}$ ), $2 \mathrm{mM}\left[{ }^{14} \mathrm{C}\right] 2 \mathrm{DG}$ (specific activity $20 \mathrm{mCi} \mathrm{mmol}^{-1}$ ), $2 \mathrm{mM}\left[{ }^{14} \mathrm{C}\right]$ mannose (specific activity $10 \mathrm{mCi} \mathrm{mmol}^{-1}$ ) or $0.5 \mathrm{mM}\left[{ }^{14} \mathrm{C}\right]$ ribose (specific activity $1 \mathrm{mCi} \mathrm{mmol}^{-1}$ ) $[1 \mathrm{mCi}=$ $37 \mathrm{MBq}]$.

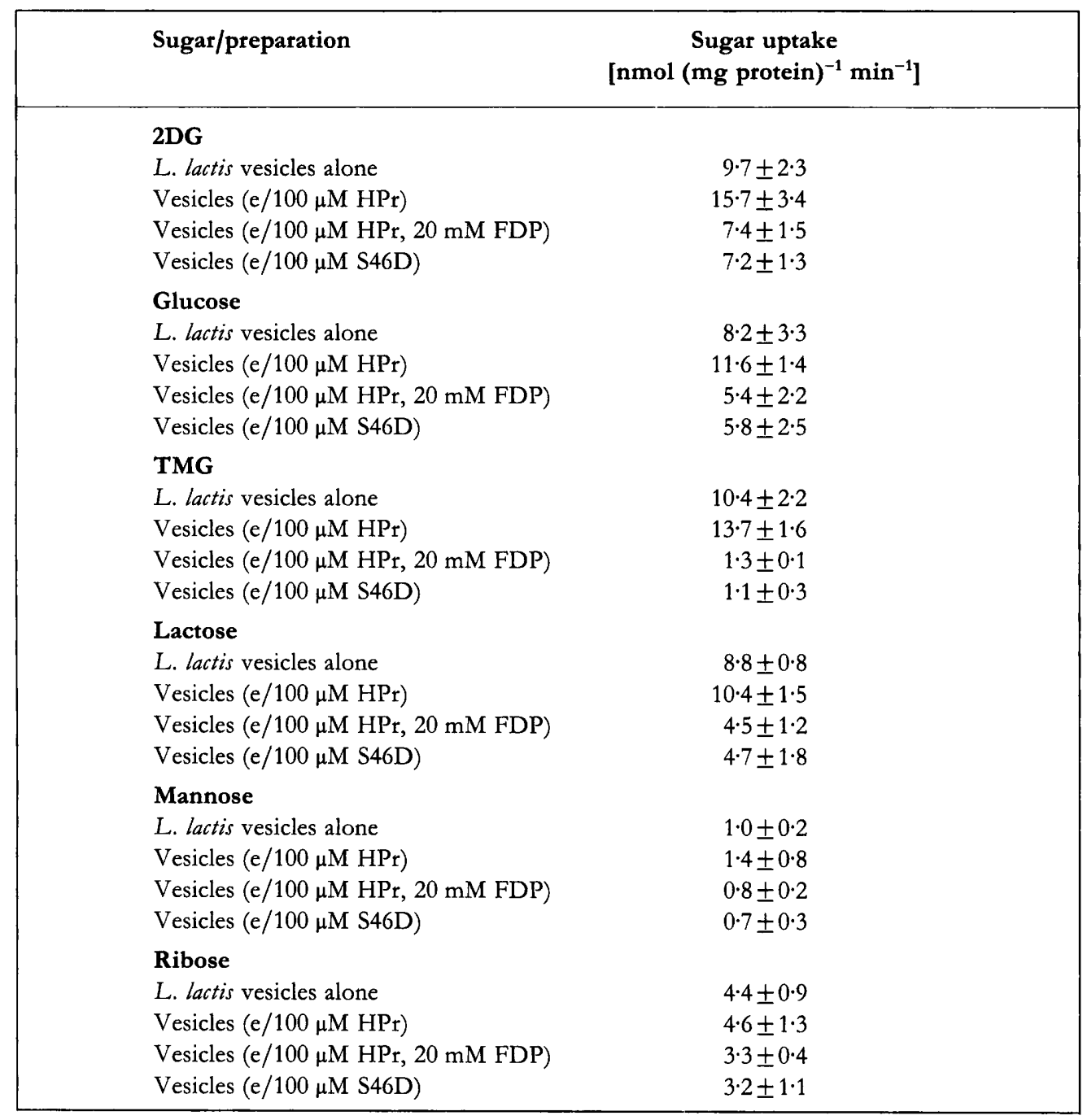

with the negatively charged aspartyl residue (S46D; Fig. $3 \mathrm{~b}, \mathrm{~d})$. In the former case, 2DG uptake occurred to an extent comparable to that observed with the wild-type $\mathrm{HPr}$, and an insignificant degree of inhibition was observed when FDP was electroporated into the vesicles (Fig. 3a). FDP could not promote 2DG expulsion in these vesicles (Fig. 3c). By contrast, employing S46D HPr, uptake of $2 D G$ was reduced regardless of the presence of FDP (Fig. 2b), and 2DG-preloaded vesicles rapidly lost most of the radioactive sugar, even in the absence of FDP (Fig. 3d). These results are qualitatively similar to those obtained with TMG (Ye et al., 1994a) and are consistent with the observation that the $S 46 \mathrm{D}$ mutation renders $\mathrm{HPr}$ conformationally similar to seryl phosphorylated $\mathrm{HPr}$ as has been revealed by multidimensional NMR and func- tional analyses (Reizer et al., 1989, 1992; Wittekind et al., 1990).

\section{Metabolites that influence intravesicular 2DG accumulation}

Table 2 provides information regarding the metabolites that promote inhibition of $2 \mathrm{DG}$ accumulation into $L$. lactis vesicles. The $\mathrm{HPr}(\mathrm{Ser})$ kinase is known to be activated by three metabolites in vitro, FDP, gluconate 6-P and glycerate 2-P (Reizer et al., 1984). Inhibition of $2 \mathrm{DG}$ accumulation was observed when any one of these three compounds was electroporated into the vesicles. Other metabolites, including glucose 6-P, fructose 6-P and mannose 6-P, were almost without effect. 
When $20 \mathrm{mM} \mathrm{Mg}^{2+}$ was electroporated into the vesicles together with $\mathrm{HPr}, 30-40 \%$ inhibition was observed with respect to both 2DG and TMG uptake (Table 3). Only a slight inhibitory effect was observed when HPr was not included. The inhibitory effect of $\mathrm{Mg}^{2+}$ in the presence of $\mathrm{HPr}$ may be due to activation of either the $\mathrm{HPr}(\mathrm{Ser})$ kinase or the hexose-phosphate phosphatase, both of which are dependent on $\mathrm{Mg}^{2+}$ for activity in vitro (Thompson \& Chassy, 1983; Reizer et al., 1984).

$\mathrm{Mg}^{2+}$ alone did little to enhance the inhibitory effect of either glucose 6-P or fructose 6-P, which were only weakly inhibitory with respect to sugar uptake. However, when $\mathrm{Mg}^{2+}$-ATP was added instead of $\mathrm{Mg}^{2+}$ at the same concentration, the inhibitory effects of both glucose 6-P and fructose 6-P were substantially enhanced, regardless of whether $2 \mathrm{DG}$ or TMG was the radioactive substrate for the uptake studies (Table 3). The inhibitory effects of these sugar phosphates approached those observed with FDP. $\mathrm{Mg}^{2+}$-ATP did not increase the inhibitory efficacies of the other tested compounds listed in Table 2 (data not shown). It was therefore concluded that the effects of $\mathrm{Mg}^{2+}-\mathrm{ATP}$ were specific and may result from facilitation of the conversion of the hexose monophosphates to the common glycolytic intermediate, FDP.

\section{Regulation of the uptake of metabolizable sugars}

The studies reported above, and in our earlier communication (Ye et al., 1994a), utilized non-metabolizable sugar analogues in order to facilitate interpretation of the results. Table 4 summarizes results obtained under selective conditions when the uptake of several metabolizable as well as non-metabolizable sugars was studied. It can be seen that intravesicular FDP plus wild-type $\mathrm{HPr}$, or S46D HPr alone, strongly inhibited uptake of both $\left[{ }^{14} \mathrm{C}\right]$ glucose and $\left[{ }^{14} \mathrm{C}\right]$ mannose to a degree comparable to that observed for $\left[{ }^{14} \mathrm{C}\right] 2 \mathrm{DG}$. Lactose uptake was less strongly inhibited than was TMG uptake (Table 4), possibly because the sugar concentration used in the uptake experiments was higher than that used when TMG uptake was studied. Finally, $\left[{ }^{14} \mathrm{C}\right]$ ribose uptake, which presumably occurs in $L$. lactis via an independent transport system, was also inhibited (Table 4). These studies with vesicles suggest that metabolite-promoted inhibition of the uptake of certain metabolizable sugar substrates of the PTS (and possibly of a non-PTS permease, as in the case of ribose) is mediated by seryl phosphorylation of $\mathrm{HPr}$ in vivo.

\section{Kinetic analysis of the inhibition of 2DG uptake}

The vesicles were utilized to measure the kinetic parameters for 2DG uptake under conditions of FDPpromoted inhibition (data not shown). When $\mathrm{HPr}$ $(50 \mu \mathrm{M})$ was electroporated into vesicles together with FDP, a double reciprocal plot revealed that $\mathrm{HPr}$ plus FDP decreased the $V_{\max }$ value without altering the $K_{\mathrm{m}}$ relative to the control in which only $\mathrm{HPr}$ was present. It is interesting to note that inhibition of carbohydrate uptake via the II $\mathrm{A}^{\text {glc }}$-mediated regulatory mechanism controlling permease activities in enteric bacteria also depresses the $V_{\max }$ value without affecting the $K_{\mathrm{m}}$ (Saier \& Roseman, 1976; Saier, 1989a).

\section{DISCUSSION}

In earlier studies we provided direct evidence that serine phosphorylation of HPr by an ATP-dependent, metabolite-activated protein kinase regulates (1) TMG uptake and efflux, probably via the PTS in Lactococcus lactis, (2) sugar accumulation via both the lactose: $\mathrm{H}^{+}$symporter and the glucose: $\mathrm{H}^{+}$symporter in Lactobacillus brevis, (3) the activity of a cytoplasmic sugar-phosphate phosphatase that comprises the rate-limiting step for sugar efflux in lactococci and streptococci, and (4) catabolite repression in Bacillus subtilis ('Thompson \& Chassy, 1983; Reizer et al., 1983; Thompson, 1988; Deutscher et al., 1994; Ye et al., 1994a, b, c). In all cases, metabolite-promoted inhibition of uptake can be equated with the important physiological phenomenon of inducer exclusion, while metabolite-promoted efflux of the sugar may be equated to the phenomenon of inducer expulsion (see Introduction). In this study we utilized vesicles of $L$. lactis in order to extend our earlier studies on the role of $\mathrm{HPr}$ serine phosphorylation in the regulation of TMG uptake to the regulation of $2 \mathrm{DG}$ accumulation via the glucosespecific P'TS.

The experiments reported here provide strong evidence for the supposition that metabolite-activated, kinasecatalysed phosphorylation of serine-46 in HPr of L. lactis regulates the net activity of the glucose PTS by a mechanism analogous to that previously established for the lactose PTS of this organism. The evidence is as follows. (1) Uptake of $2 D G$ is dependent on PEP and is stimulated by HPr in a process dependent on the activesite histidine (His-15) but not on the regulatory serine (Ser-46). (2) Vesicles that are largely depleted of HPr are insensitive to inhibition of $2 D G$ uptake and stimulation of 2DG efflux by glucose metabolites, but electroporation of wild-type HPr into the vesicles restores sensitivity of the glucose permease to metabolite-promoted regulation. (3) Intravesicular metabolites of glucose such as FDP, gluconate 6-phosphate and 2-phosphoglycerate, but not various other metabolites, promote inhibition of $2 \mathrm{DG}$ uptake and/or stimulation of $2 \mathrm{DG}$ release. This specificity corresponds to the activation specificity of many Grampositive bacterial HPr kinases, including that from $L$. lactis (Reizer et al., 1988; J. J. Ye \& M. H. Saier, Jr, unpublished observations). (4) Replacement of serine-46 with alanine (S46A HPr), a neutral, non-phosphorylatable residue, renders the protein completely inactive as a regulatory molecule. (5) Replacement of serine-46 with aspartate (S46D HPr), a permanently negatively charged residue resembling phosphorylated serine with regard to its charge, gives rise to a constitutively regulated permease, in agreement with conformational and functional properties of the mutant protein as described previously (Reizer et al., 1989, 1992; Wittekind et al., 1990). (6) Replacement of the active-site histidine by alanine (H15A) in HPr has little or no effect on regulation of the glucose 
permease, showing that phosphorylation of this residue does not play a role in regulation. (7) Finally, regulation depresses the maximal extent of $2 \mathrm{DG}$ accumulation without altering the apparent $K_{\mathrm{m}}$ for this process. The same was observed for TMG accumulation in this organism (Ye et al., 1994a).

In our previous studies with $L$. lactis vesicles (Ye et al., 1994a) we were puzzled by the observation that glucose and FDP, but not glucose 6-P or fructose 6-P, inhibited TMG uptake and stimulated TMG-6-P hydrolysis and TMG efflux. Two possibilities may be considered to provide explanations for this observation. First, free $\mathrm{HPr}$ is readily phosphorylated on either His-15 by PEP and Enzyme I or on Ser-46 by ATP and the HPr kinase. The phosphorylation of His-15 greatly inhibits phosphorylation of Ser-46 and vice versa. Since the vesicles which contain Enzyme I are provided with excess PEP, HPr is probably phosphorylated on His-15 in the absence of glucose. The glucose then serves both to provide FDP and to dephosphorylate $\mathrm{HPr}(\mathrm{His}-\mathrm{P})$. Second, the vesicles may be able to convert glucose but not hexose monophosphates to FDP. A complex of PTS and glycolytic enzymes may be present in association with the membrane so that the product of the PTS-catalysed transport reaction is passed directly from the Enzyme IIC ${ }^{\text {glc }}$ active site to that of phosphoglucoisomerase, and the product of the reaction catalysed by phosphoglucoisomerase is then passed directly to the active site of phosphofructokinase to yield FDP. Evidence has been presented for the presence of a PTS enzyme complex in E. coli membrane vesicles with much greater activity than the dissociated constituents (Saier et al., 1982). Assuming this to be the case in L. lactis, sufficient ATP must be present in association with the membranes to allow rapid phosphorylation of fructose-6-P. Since the vesicles accumulate appreciable 2DG-P or TMG-P without addition of exogenous PEP (Table 1 and Ye et al., 1994a), this suggestion seems reasonable. Interestingly, the inhibitory efficacy of glucose 6-P or fructose 6-P was greatly enhanced when $\mathrm{Mg}^{2+}-\mathrm{ATP}$ (but not $\mathrm{Mg}^{2+}$ alone) was electroporated into the vesicles (Table 3 ). The availability of this energy source may therefore allow functional access of the hexose monophosphates to the relevant enzymes. The availability of a vesicular system to study metabolite channeling may permit establishment of this phenomenon and elucidation of the mechanism by which this poorly characterized but long-postulated phenomenon occurs (Saier et al., 1982; Srere, 1987; Mayer, 1993).

It is interesting to note that the vesicles contain HPr in amounts and in a form that is capable of catalysing PTS sugar uptake but not effecting regulation. This observation could be due to either a quantitative or a qualitative difference. First, higher concentrations of $\mathrm{HPr}(\mathrm{Ser}-\mathrm{P})$ may be required for regulation than are required for $\mathrm{HPr}(\mathrm{His}-$ P) catalysis. Second, the vesicular $L$. lactis HPr may be present in association with a complex of PTS and glycolytic enzymes as suggested above. A nonassociated form of $\mathrm{HPr}$ may be required to effect regulation. If the sugar-phosphate phosphatase that is activated by $\mathrm{HPr}(\operatorname{Ser}-\mathrm{P})$ is not present within this 'glycolytic com- plex', then the complexed HPr would not be expected to be accessible to the sugar-phosphate phosphatase. Hence, the complexed HPr would be inactive in regulation. Further experiments will be required to determine the basis for this difference.

Several observations reported in this communication are likely to prove to be of physiological importance. Uptake of metabolizable as well as non-metabolizable sugars is apparently inhibited by seryl phosphorylation of HPr. The fact that glucose uptake is inhibited suggests that the function of $\mathrm{HPr}(\mathrm{Ser})$ phosphorylation is not merely to create a hierarchy of preferred sugars with glucose at the top. Metabolite activation of the kinase may serve more generally as a feedback mechanism to control the entry of carbohydrates into the cell, even for the dominant glucose permease, in order to prevent the uptake of more carbohydrate than is needed by the cell. This possibility had been suggested in an early review article (Deutscher \& Saier, 1988). However, subsequent in vivo experiments with Staphylococcus aureus and Bacillus subtilis strains did not provide evidence for this suggestion (Reizer et al., 1989, 1992). Most recent experiments have confirmed that in $B$. subtilis, uptake of sugars via the PTS is not appreciably inhibited by $\operatorname{HPr}(\mathrm{Ser})$ phosphorylation and that the $\mathrm{HPr}$ (Ser-P) derivative functions in this organism to effect one form of catabolite repression (Deutscher et al., 1994).

The fact that ribose uptake into vesicles was inhibited by $\mathrm{HPr}$ (Ser-P) suggests that the mechanism of non-PTS permease regulation by $\mathrm{HPr}(\operatorname{Ser}-\mathrm{P})$, demonstrated previously in Lactobacillus brevis ( $\mathrm{Ye}$ et al., 1994b, c), is operative in Lactococcus lactis. It is also possible, however, that dephosphorylation of the intracellular or intravesicular sugar phosphates via the $\mathrm{HPr}(\mathrm{Ser}-\mathrm{P})$-stimulated sugar-phosphate phosphatase accounts for much of the regulatory phenomena reported here and in our earlier report (Ye et al., 1994a). The sugar specificity for regulation may correlate either with that of the PTS or with that of the sugar-phosphate phosphatase. Further studies will be required to define the range of permeases, enzymes and regulatory systems that have evolved sensitivity to $\mathrm{HPr}($ Ser-P) inhibition.

\section{ACKNOWLEDGEMENTS}

We are grateful to Mary Beth Hiller for excellent assistance in the preparation of this manuscript. This work was supported by US Public Health Service grants 5RO1AI 21702 and 2RO1AI 14176 from the National Institutes of Allergy and Infectious Diseases.

\section{REFERENCES}

Deutscher, J. \& Saier, M. H., Jr (1983). ATP-dependent protein kinase-catalyzed phosphorylation of a seryl residue in $\mathrm{HPr}$, the phosphoryl carrier protein of the phosphotransferase system in Streptococcus pyogenes. Proc Natl Acad Sci US A 80, 6790-6795.

Deutscher, J. \& Saier, M. H., Jr (1988). Protein phosphorylation in bacteria - regulation of gene expression, transport function, and metabolic processes. Angew Chemie Int Ed Engl 27, 1040-1049.

Deutscher, J., Reizer, J., Fischer C., Galinier, A., Saier, M. H., Jr, 
\& Steinmetz, M. (1994). Loss of protein kinase-catalyzed phosphorylation of $\mathrm{HPr}$, a phosphocarrier protein of the phosphotransferase system, by mutation of the $p t s H$ gene confers catabolite repression resistance to several catabolic genes of Bacillus subtilis. J Bacteriol 176, 3336-3344.

Kaback, H. R. (1972). Bacterial membranes. Methods Enzymol 22, 99-120.

Kundig, W. \& Roseman, S. (1971). Sugar transport. I. Isolation of a phosphotransferase system from Escherichia coli.J Biol Chem 246, 1393-1406.

Mayer, F. (1993). Principles of functional and structural organization in the bacterial cell: 'compartments' and their enzymes. FEMS Microbiol Rev 104, 327-346.

Postma, P., Lengeler, J. \& Jacobson, G. R. (1993). Phosphoenolpyruvate:carbohydrate phosphotransferase systems of bacteria. Microbiol Rev 57, 543-594.

Reizer, J. \& Panos, C. (1980). Regulation of $\beta$-galactoside phosphate accumulation in Streptococcus pyogenes by an expulsion mechanism. Proc Natl Acad Sci US A 77, 5497-5501.

Reizer, J., Novotny, M. J., Panos, C. \& Saier, M. H., Jr (1983). The mechanism of inducer expulsion in Streptococcus pyogenes: a two step process activated by ATP. $J$ Bacteriol 156, 354-361.

Reizer, J., Novotny, M. J., Hengstenberg, W. \& Saier, M. H., Jr (1984). Properties of ATP-dependent protein kinase from Streptococcus pyogenes that phosphorylates a seryl residue in $\mathrm{HPr}$, a phosphocarrier protein of the phosphotransferase system. J Bacteriol 160, 333-340.

Reizer, J., Saier, M. H., Jr, Deutscher, J., Grenier, F., Thompson, J. \& Hengstenberg, W. (1988). The phosphoenolpyruvate:sugar phosphotransferase system in Gram-positive bacteria: properties, mechanism and regulation. CRC Crit Rev Microbiol 15, 297-338.

Reizer, J., Sutrina, S. L., Saier, M. H., Jr, Stewart, G. C., Peterkofsky, A. \& Reddy, P. (1989). Mechanistic and physiological consequences of $\mathrm{HPr}(\mathrm{ser})$ phosphorylation on the activities of the phosphoenolpyruvate: sugar phosphotransferase system in Grampositive bacteria : studies with site-specific mutants of HPr. EMBO J 8, 2111-2120.

Reizer, J., Sutrina, S. L., Wu, L.-F., Deutscher, J., Reddy, P. \& Saier, M. H., Jr (1992). Functional interactions between proteins of the phosphoenolpyruvate: sugar phosphotransferase systems of Bacillus subtilis and Escherichia coli. J Biol Chem 267, 9158-9169.

Romano, A. H., Brino, G., Peterkofsky, A. \& Reizer, J. (1987). Regulation of $\beta$-galactoside transport and accumulation in heterofermentative lactic acid bacteria. J Bacteriol 169, 5589-5596.

Saier, M. H., Jr (1985). Mechanisms and Regulation of Carbohydrate Transport in Bacteria. Orlando, FL: Academic Press.

Saier, M. H., Jr (1989a). Protein phosphorylation and allosteric control of inducer exclusion and catabolite repression by the bacterial phosphoenolpyruvate:sugar phosphotransferase system. Microbiol Rev 53, 109-120.

Saier, M. H., Jr (1989b). Involvement of the bacterial phospho- transferase system in diverse mechanisms of transcriptional regulation. Res Microbiol 140, 349-354.

Saier, M. H., Jr \& Reizer, J. (1992). Proposed uniform nomenclature for the proteins and protein domains of the bacterial phosphoenolpyruvate:sugar phosphotransferase system. I Bacteriol 174, 1433-1438.

Saier, M. H., Jr \& Roseman, S. (1976). Sugar transport. Inducer exclusion and regulation of the melibiose, maltose, glycerol, and lactose transport systems by the phosphoenolpyruvate:sugar phosphotransferase system. J Biol Chem 251, 6606-6615.

Saier, M. H., Jr, Cox, D. F., Feucht, B. U. \& Novotny, M. J. (1982). Evidence for the functional association of Enzyme I and HPr of the phosphoenolpyruvate-sugar phosphotransferase system with the membrane in sealed vesicles of Escherichia coli. J Cell Biochem 18, 231-238.

Saier, M. H., Jr, Reizer, J. \& Deutscher, J. (1992). Protein phosphorylation and the regulation of sugar transport in Gramnegative and Gram-positive bacteria. In Adenine Nucleotides in Cellular Energy Transfer and Signal Transduction, pp. 181-190. Edited by S. Papa, A. Azzi \& J. M. Tager. Basel: Birkhäuser Verlag.

Srere, P. A. (1987). Complexes of sequential metabolic enzymes. Annu Rev Biochem 56, 89-124.

Thompson, J. (1988). Lactic acid bacteria: model systems for in vivo studies of sugar transport and metabolism in Gram-positive organisms. Biochimie 70, 325-336.

Thompson, J. \& Chassy, B. M. (1983). Intracellular hexose-6phosphate: phosphohydrolase from Streptococcus lactis: purification, properties, and function. $J$ Bacteriol 156, 70-80.

Thompson, J. \& Saier, M. H., Jr (1981). Regulation of methyl- $\beta$-Dthiogalactopyranoside-6-phosphate accumulation in Streptococcus lactis by exclusion and expulsion mechanisms. I Bacteriol 146, 885-894.

Wittekind, M., Reizer, J., Deutscher, J., Saier, M. H., Jr \& Klevit, R. E. (1990). Common structural changes accompany the functional inactivation of $\mathrm{HPr}$ by seryl phosphorylation or by serine to aspartate substitution. Biochemistry 28, 9908-9912.

Ye, J. J., Reizer, J., Cui, X. \& Saier, M. H., Jr (1994a). Inhibition of the phosphoenolpyruvate: lactose phosphotransferase system and activation of a cytoplasmic sugar-phosphate phosphatase in Lactococcus lactis by ATP-dependent metabolite-activated phosphorylation of serine-46 in the phosphocarrier protein, HPr. J Biol Chem 269, 11837-11844.

Ye, J. J., Reizer, J., Cui, X. \& Saier, M. H., Jr (1994b). ATPdependent phosphorylation of serine in HPr regulates lactose: $\mathrm{H}^{+}$ symport in Lactobacillus brevis. Proc Natl Acad Sci USA 91, 3102-3106

Ye, J. J., Neal, J. W., Cui, X., Reizer, J. \& Saier, M. H., Jr (1994c). Regulation of the glucose: $\mathrm{H}^{+}$symporter by metabolite-activated ATP-dependent phosphorylation of $\mathrm{HPr}$ in Lactobacillus brevis. J Bacteriol 176, 3484-3492.

Received 11 April 1994; revised 16 June 1994; accepted 25 July 1994. 